\title{
Field Evaluation of Phomopsis amaranthicola, A Biological Control Agent of Amaranthus spp.
}

\author{
E. N. Rosskopf, USDA/ARS, U.S. Horticultural Research Laboratory, Ft. Pierce, FL 34945, R. Charudattan, Pro- \\ fessor of Plant Pathology, J. T. DeValerio, Biological Scientist, Plant Pathology, and W. M. Stall, Professor of \\ Horticultural Sciences, University of Florida, Gainesville 32611
}

\begin{abstract}
Rosskopf, E. N., Charudattan, R., DeValerio, J. T., and Stall, W. M. 2000. Field evaluation of Phomopsis amaranthicola, a biological control agent of Amaranthus spp. Plant Dis. 84:12251230.

There are approximately 60 species in the genus Amaranthus, of which seven are used as grains, leafy vegetables, or ornamentals. The majority of the remaining species are considered important weeds. A new fungal species, Phomopsis amaranthicola, isolated from stem and leaf lesions on an Amaranthus sp. plant, was found to be pathogenic to 22 species of Amaranthus tested. The efficacy of this fungus was tested in field trials using one or two postemergent applications of the fungus consisting of two concentrations of conidia or mycelial suspensions. Species tested for susceptibility in the field included Amaranthus hybridus, A. lividus, A. viridus, A. spinosus, and a triazine-resistant $A$. hybridus. The cumulative disease incidence data for each treatment within each species were plotted versus time using regression for lifetime data. Plant mortality was recorded 2, 4, and 6 weeks after inoculation. There were significant differences between the treatment effects in the control plots versus the plots treated with $P$. amaranthicola. The highest level of control was obtained in the first trial when the fungus was applied at $6 \times$ $10^{7}$ conidia per ml. Final mortality of all species, except A. hybridus, reached $100 \%$ in inoculated plots 25 days earlier than in noninoculated control plots. Conidial suspensions were more effective in controlling the species in the second trial than were mycelial suspensions. Spread of the pathogen to noninoculated control plots was faster in the second year than in other years. High levels of plant mortality were achieved in plots of A. spinosus, A. lividus, and A. viridis. A. hybridus and the triazine-resistant $A$. hybridus were not effectively controlled in the second year due to the advanced stage of plant growth (8 to 10 true leaves) at the time of pathogen application. Results confirmed that $P$. amaranthicola is an effective biocontrol agent of some of the Amaranthus spp. tested.
\end{abstract}

Additional keywords: amaranth, pigweed

Previous studies have established Phomopsis amaranthicola Rosskopf, Charudattan, Shabana, \& Benny is a potential biological control agent for weeds in the genus Amaranthus (11). The biocontrol efficacy of this pathogen has been determined in greenhouse and growth chamber trials, and the fungus is restricted in its host range to Amaranthus spp. only (108).

Corresponding author: E. N. Rosskopf E-mail: erosskopf@ushrl.ars.usda.gov

This research was supported in part by funds provided by Special Grants in Tropical Agriculture, Caribbean Basin Administrative Group (CBAG), USDA Contract 94-34135-0649 to R. Charudattan and W. M. Stall and by the Florida Agricultural Experiment Station. Contribution R07226 Florida Agricultural Experiment Station Journal Series.

Accepted for publication 31 July 2000.

Publication no. D-2000-0825-02R

This article is in the public domain and not copyrightable. It may be freely reprinted with customary crediting of the source. The American Phytopathological Society, 2000.
Field evaluation of biological effectiveness is one of the most important components of a complete evaluation of a pathogen's weed-control potential. Although a pathogen may perform effectively in greenhouse or growth-chamber experiments, its use in the field is often characterized by variable levels of effectiveness against the target weed. For example, Puccinia carduorum was evaluated in the field for the control of musk thistle (Carduus theormeri) (2). Although this rust fungus caused significant reductions in plant biomass accumulation after both single and multiple applications of uredospores in greenhouse trials, its effectiveness in the field was limited to accelerated senescence and reductions in seed production.

Colletotrichum orbiculare gave good control of Xanthium spinosum when tested in small-scale field plots. In further tests at four field sites with variable environmental conditions, $100 \%$ plant mortality resulted at two sites with artificial dew periods of $18 \mathrm{~h}$. In sites that were not treated with an artificial dew period, the maximum plant mortality reached only $50 \%$ (1). When this pathosystem was later evaluated using spores suspended in oil emulsions in the absence of artificial dew, the levels of weed control were dramatically increased (7).

The effect of Colletotrichum truncatum on the growth of hemp sesbania (Sesbania exaltata) was tested in the field by applying conidia of the pathogen at two rates in either an aqueous suspension or an invert emulsion. The maximum level of weed mortality in plots treated with the aqueous conidial suspension was only $42 \%$, while the invert emulsion suspensions of conidia yielded $97 \%$ mortality in plots treated with the higher application rate. This was comparable to control with the herbicide acifluorfen. The effect of the invert emulsion applied without the fungus was statistically similar to the effect of the pathogen in the aqueous suspension (3).

The control of Amaranthus albus by the biocontrol agent Microsphaeropsis amaranthi is an example of a successful transition from greenhouse to field use. This pathogen, which was extremely efficacious on the target weed in controlled, growthchamber studies, also performed well in the field, with 96 to $99 \%$ mortality after applications of $1 \times 10^{6}$ or $6 \times 10^{6}$ conidia per $\mathrm{ml}$. This system was tested in only one season at one location (8).

Commercialization of fungal plant pathogens as biological control agents requires that the agents perform well in the field as well as in the greenhouse phase of testing. For instance, the two commercially available agents in the United States, Phytophthora palmivora, marketed as DeVine, and Colletotrichum gloeosporiodes $\mathrm{f}$. sp. aeschynomene, sold as Collego, were found to perform highly successfully in field trials prior to their commercial development $(4,9)$

The objective of our study was to evaluate the potential of $P$. amaranthicola as a biocontrol agent for Amaranthus spp. under field conditions.

\section{MATERIALS AND METHODS}

Inoculum and plants. For the production of conidia, $P$. amaranthicola was cultured on V8 juice agar plates for 21 to 28 days at $25^{\circ} \mathrm{C}$ with a 12 -h diurnal light cycle. Conidia were harvested by rinsing plates with sterile deionized water, and the spores were counted with the aid of a hemacytometer and diluted to the desired concentrations. Mycelial inoculum was 
produced in V8 broth medium in Roux bottles for 21 days. The mycelium was filtered through cheesecloth, gently pressed to remove excess liquid, and blended for 3 $\mathrm{s}$ in a Waring blender at the rate of $5 \mathrm{~g}$ of mycelium per milliliter of sterile deionized water. The resulting suspension was used as inoculum. Inoculum was freshly prepared before each application.

Plants were grown from seed in the greenhouse, transplanted into flats, allowed to grow for 10 days, and transplanted in the per $\mathrm{m}^{2}$ of plot. Species were not combined within plots. These plants were allowed to grow for 1 week before inoculation.

1993 trial. The 1993 field trial was performed in Gainesville, FL. The Amaranthus species tested were chosen based upon their economic importance and susceptibility (a minimum of $50 \%$ mortality) in field with 10 to 20 plants of each species

greenhouse trials. The species chosen included A. hybridus, A. viridus, A. lividus, A. spinosus, and a triazine-resistant accession of A. hybridus (accession PI 604673). Seeds were obtained from the USDA, ARS, National Genetic Resources Program, North Central Regional Plant Introduction Station, Ames, IA, and from T. Bewick, University of Florida, Gainesville.

The field plots were arranged in a completely randomized design consisting of four species (10 plants per species per plot) and the herbicide-resistant accession and eight treatments with five replicates per treatment. Plots were $1 \mathrm{~m}^{2}$ with $1.5-\mathrm{m}$ alleys. Treatments 1 to 4 consisted, respectively, of a single application of a psyllium mucilloid control (Metamucil, Procter \& Gamble, Cincinnati, OH; $0.5 \%$ wt/vol), mycelial suspension (50 g/liter), low concentration of conidia $\left(1 \times 10^{6}\right.$ conidia per

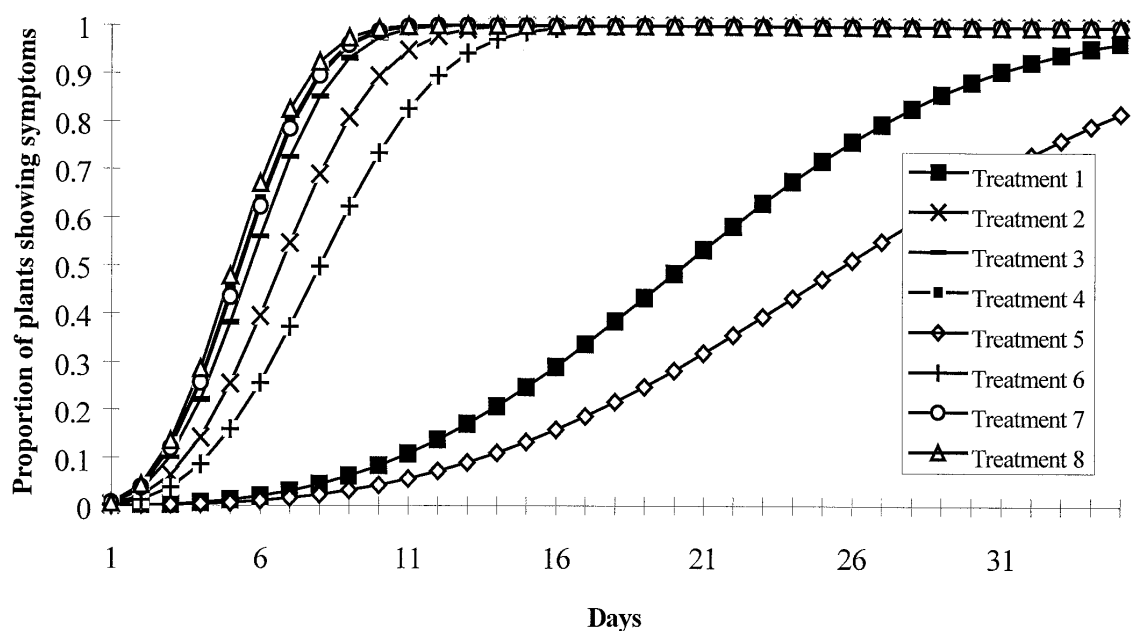

Fig. 1. Weibull model of disease progress on Amaranthus viridus in 1993 inoculated with Phomopsis amaranthicola. Treatments consisted of a single (1 to 4$)$ or double (5 to 8) application of the following: psyllium mucilloid alone (1,5), mycelial suspension $(2,6), 1.0 \times 10^{6}$ conidia per $\mathrm{ml}$ suspension $(3,7)$, and $6.0 \times 10^{7}$ conidia per $\mathrm{ml}$ suspension $(4,8)$.

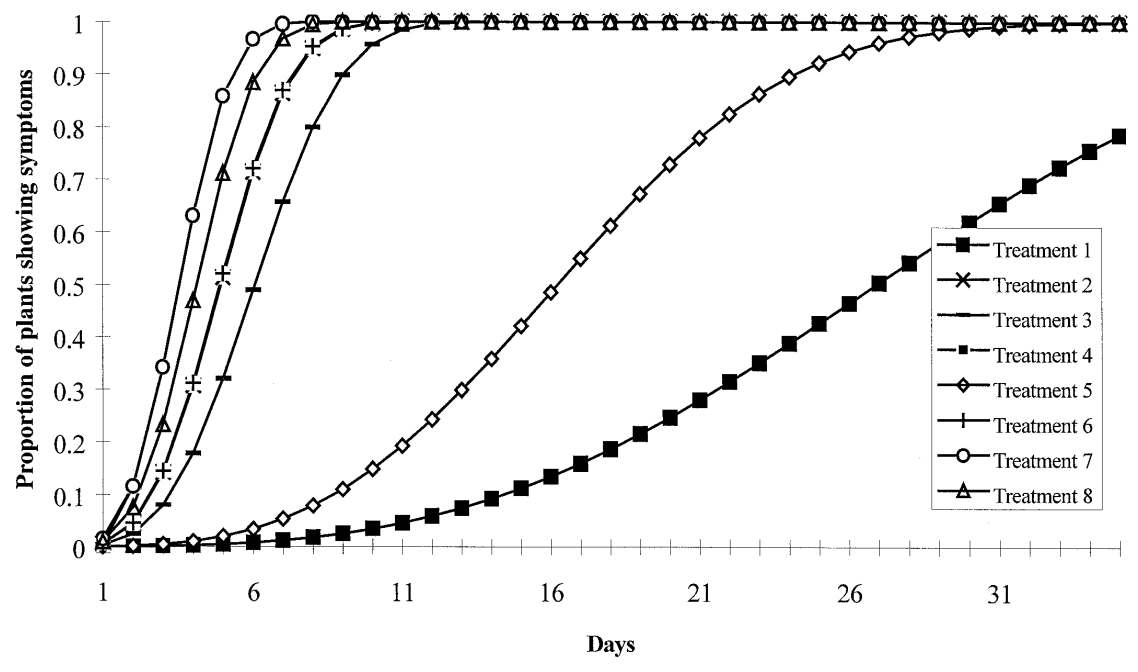

Fig. 2. Weibull model of disease progress on Amaranthus lividus in 1993 inoculated with Phomopsis amaranthicola. Treatments consisted of a single (1 to 4 ) or double (5 to 8) application of the following: psyllium mucilloid alone $(1,5)$, mycelial suspension $(2,6), 1.0 \times 10^{6}$ conidia per $\mathrm{ml}$ suspension $(3,7)$, and $6.0 \times 10^{7}$ conidia per $\mathrm{ml}$ suspension $(4,8)$. $\mathrm{ml})$, or a high concentration of conidia $(6 \times$ $10^{7}$ conidia per $\left.\mathrm{ml}\right)$. All fungal suspensions were amended with $0.5 \%$ psyllium mucilloid, which was used as a humectant. The control plants were not protected with fungicide sprays since no chemical treatment was allowed in this farm used for organically grown crops. Treatments 5 to 8 were the same as treatments 1 to 4 , but were applied twice at 10-day intervals. Each treatment was applied with a $\mathrm{CO}_{2}$ backpack sprayer at a rate of approximately $90 \mathrm{ml}$ per plot, which is equivalent to approximately 950 liters/ha, using 138 $\mathrm{kPa}$ of pressure. All application were made at dusk.

Proportion of diseased plants based on symptom expression was recorded on a weekly basis, and the data were converted to percentage of diseased plants in each plot. Plant mortality was recorded in the same manner. Symptomatic tissue was taken from three plants in each plot (including tissues from control plants that became diseased), surface-sterilized, and plated onto potato dextrose agar amended with chloramphenicol $(2.5 \mathrm{mg} / \mathrm{liter})$ and streptomycin sulfate $(3.7 \mathrm{mg} / \mathrm{liter})$. The cumulative disease incidence data were plotted versus time using regression for lifetime data (6). Disease incidence and percentages of mortality were transformed using the arcsine square-root transformation, and variance and interactions were analyzed using the General Linear Models (GLM) procedure with repeated-measures analysis; least-squares mean was used for mean separation. All analyses were performed using PC-SAS software (SAS System v. 6.12, SAS Institute, Cary, NC). Data for each species were analyzed separately.

1994 and 1995 trials. Field trials were performed in the same manner in 1994 and 1995 as in 1993, except that they were performed at the Millhopper Horticultural Sciences Unit of the University of Florida, Gainesville. The 1994 and 1995 field experiments had a completely randomized block design with the replicate plots as the blocking factor. Plots were $1 \mathrm{~m}^{2}$ with $1-\mathrm{m}$ alleys, and there were 20 plants per plot. The same treatments were used as in 1993 and were applied in the same manner. Data for each species were collected as in 1993, and percentages of dead plants were transformed using the arcsine square-root transformation. Mortality data were analyzed using the GLM procedure (PC-SAS software) with repeated-measures analysis, and least-squares means were used for mean separation. All analyses were performed using the SAS statistical software package.

\section{RESULTS}

1993 trial. Symptoms first appeared in the field on A. lividus 4 days after treatment with the low concentration of conidia. The first instance of mortality also occurred in the same treatment. 
The cumulative disease incidence data versus time for each species plotted using regression for lifetime data fit the Weibull model best. Disease within inoculated plots progressed much more rapidly than in the control plots (Figs. 1 to 4 ). This was the case for all species tested (data for $A$. hybridus not shown).

Mortality of A. lividus treated with one application of the high concentration of conidia was $73 \%$ within 2 weeks of inoculation (Table 1). This level of mortality was not significantly different from that in any of the other treatments containing $P$. amaranthicola, but was significantly higher than that in both controls (mucilloid alone). Mortalities of the other species at this time were not significant. At 2 weeks, A. hybridus plants treated with a single or a double application of a high concentration of conidia had 34 and $37 \%$ plant mortality. These levels of mortality were not significantly different from the levels of the other treatments with $P$. amaranthicola, but were greater than the control treatments.

Greater than $50 \%$ control of A. lividus, A. viridus, A. spinosus, and A. hybridus (triazine-sensitive) was achieved with at least one treatment by the fourth week after inoculation (Table 1). Mortality of $A$. lividus 4 weeks after inoculation ranged from 66 to $88 \%$ in plots treated with a suspension of $P$. amaranthicola. These differences in mortality levels were not significant, but all were significantly greater than mortality in plants treated with the mucilloid alone. Control of $A$. viridus ranged from 54 to $77 \%$ in the plots treated with double applications of conidia. Mortality of A. spinosus ranged from 24 to $70 \%$ in fungus-treated plots. Control of $A$. hybridus ranged from 67 to $100 \%$ in plots treated with the fungus, with no significant differences between those treatments. Mortalities in plots treated with the fungus were significantly higher than in the control treatments. Control of the triazine-resistant A. hybridus was very low at 4 weeks after inoculation, ranging from 0 to $11 \%$.

Greater than $90 \%$ mortality was achieved for each species by 6 weeks after inoculation, except the triazine-resistant $A$. hybridus, which had a maximum of only $36 \%$ mortality (Table 1). Considerable weed mortality occurred in most of the control plots by 6 weeks after inoculation. Although plots were separated by $1.5-\mathrm{m}$ alleys, spread of the pathogen to control plots was evident within 2 weeks after inoculation.

1994 trial. The effects of treatment and time were significant for the species $A$. lividus, A. viridus, and A. spinosus $(P<$ $0.05)$, and there was a treatment-by-time interaction $(P<0.10)$ for all species tested, with the exception of $A$. hybridus. The treatment effect was not significant for either A. hybridus accession.

The first symptoms occurred in plots of $A$. lividus treated with conidial suspensions of
P. amaranthicola. These symptoms were visible within 4 days after inoculation. There were no significant levels of mortality for any of the test species by 2 weeks (Table 2).

Four weeks after inoculation, plant mortality in A. lividus plots treated with a double application of the high concentration of conidia had reached $95 \%$ (Table 2). Mortality in these plots was significantly greater than that in the control plots, but not different from mortality in any of the plots treated with conidia. Mortality in plots treated with double applications of a high concentration of conidia was significantly greater than in plots treated with mycelium. Plants in control plots began to die by 4 weeks after inoculation in fungustreated plots.

Mortality of $A$. viridus treated with conidial suspensions of the fungus was significantly greater than that in the control plots 4 weeks after inoculation, ranging between 41 and $58 \%$ in the treated plots. The mortality in plots treated with mycelia was not significantly different from that in the control plots. Mortality of A. spinosus 4 weeks after inoculation reached $39 \%$ in plots treated with a double application of the high concentration of conidia. This level of mortality was not significantly different from a single application of the same conidial concentration, which resulted in $31 \%$ mortality, but was significantly greater than mortality levels in all other treatments. Control of the two $A$. hybridus accessions was not significant at 4 weeks after inoculation.

Pigweed mortality at 6 weeks after inoculation reached $100 \%$ in plots containing A. lividus treated with single applications

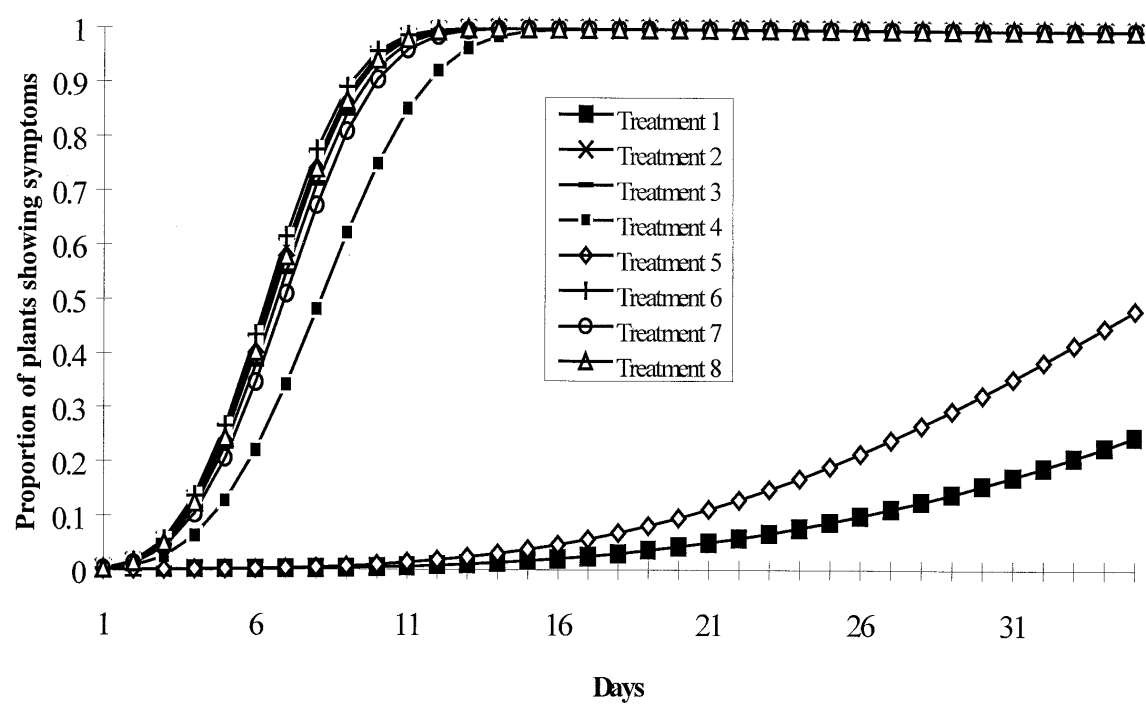

Fig. 3. Weibull model of disease progress on the triazine-resistant accession of Amaranthus hybridus in 1993 inoculated with Phomopsis amaranthicola. Treatments consisted of a single (1 to 4) or double (5 to 8) application of the following: psyllium mucilloid alone $(1,5)$, mycelial suspension $(2,6)$, $1.0 \times 10^{6}$ conidia per $\mathrm{ml}$ suspension $(3,7)$, and $6.0 \times 10^{7}$ conidia per ml suspension $(4,8)$.

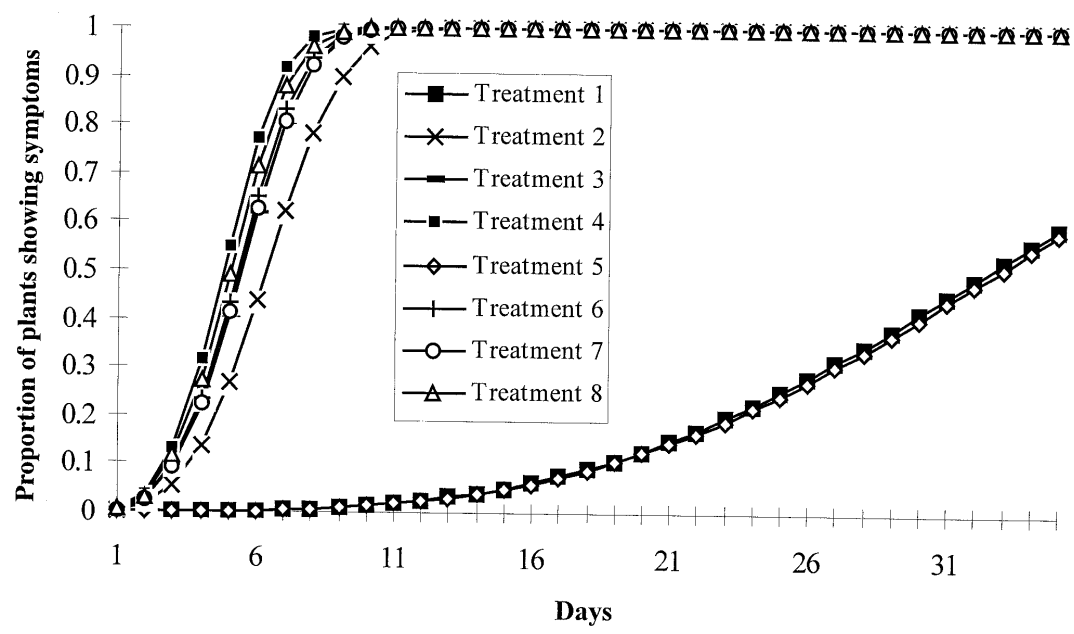

Fig. 4. Weibull model of disease progress on Amaranthus spinosus in 1993 inoculated with Phomopsis amaranthicola. Treatments consisted of a single (1 to 4) or double (5 to 8) application of the following: psyllium mucilloid alone $(1,5)$, mycelial suspension $(2,6), 1.0 \times 10^{6}$ conidia per $\mathrm{ml}$ suspension $(3,7)$, and $6.0 \times 10^{7}$ conidia per ml suspension $(4,8)$. 
of conidial suspensions. Plant mortality in control plots of this species increased from $12 \%$ at week 4 , to 72 and $80 \%$ at week 6 , and there were no significant differences between control and fungus-treated plots (Table 2 ) by this time. Up to $96 \%$ mortality occurred in plots of $A$. viridus treated with suspensions of conidia, but no significant differences occurred among any of the treatments or controls at week 6. A. spinosus plots treated with a single application of a low concentration of conidia had $70 \%$ plant mortality. This was significantly higher than mortality in control plots, but not different from mortality levels after other single applications or the double application of a high concentration of conidia. Control of both A. hybridus accessions was insignificant.

1995 trial. Interpretations of the results of the 1995 study were complicated by the presence of a substantial amount of insect damage to plants in all plots from an unidentified lepidopteran. No insecticide was applied because the effect of insecticides on the efficacy of $P$. amaranthicola was unknown at the time of this study. Treatment effects were significant for $A$. lividus $(P=0.0050)$ and $A$. spinosus $(P=0.0025)$. Single and double applications of the most highly concentrated conidial suspensions resulted in the greatest mortality. Time (intervals when disease and mortality assessments were made) was a significant factor for A. lividus, A. spinosus, and $A$. viridus $(P=0.0001)$, with no interaction between treatment and time $(P<0.05)$. Time was also significant for both $A$. hybridus accessions $(P=0.0001)$ with interactions between treatment and time.

Mortality for A. lividus at 2 weeks was $26 \%$ in plots treated with the single application of a high concentration of conidia. This was not statistically different from the mortality levels in other treatments or the control. Mortality levels of 29 and 38\% were achieved by the second week after inoculation in plots of $A$. spinosus in applications of a high concentration of conidia, but these were not significantly different from mortality in the control plots (Table 3 ). Low levels of mortality for other species after 2 weeks were not significantly different among treatments.

Mortality in plots of A. lividus 4 weeks after inoculation was $73 \%$ in the double application of the high concentration of conidia. This was significantly higher than mortality in control plots (Table 3), but not significantly better control than was achieved in other plots treated with conidial suspensions. Mortalities in plots of $A$. viridus and the two A. hybridus accessions were insignificant. Seventy-eight percent plant mortality occurred in A. spinosus plots treated with a double application of

Table 1. Pigweed (Amaranthus spp.) mortality at 2, 4, and 6 weeks after inoculation with Phomopsis amaranthicola in the 1993 field trial

\begin{tabular}{|c|c|c|c|c|c|c|c|c|c|c|c|c|c|c|c|c|}
\hline \multirow[b]{3}{*}{ Treatment } & \multirow[b]{3}{*}{ Applic. } & \multicolumn{15}{|c|}{ Percent mortality $^{x}$} \\
\hline & & \multicolumn{3}{|c|}{ A. lividus } & \multicolumn{3}{|c|}{ A. viridus } & \multicolumn{3}{|c|}{ A. spinosus } & \multicolumn{3}{|c|}{ A. hybridus } & \multicolumn{3}{|c|}{ A. hybridus ${ }^{\mathrm{y}}$} \\
\hline & & $2 \mathrm{wk}$ & $4 \mathrm{wk}$ & 6 wk & 2 wk & 4 wk & $6 \mathrm{wk}$ & $2 \mathrm{wk}$ & $4 \mathrm{wk}$ & $6 \mathrm{wk}$ & $2 \mathrm{wk}$ & 4 wk & 6 wk & 2 wk & 4 wk & $6 \mathrm{wk}$ \\
\hline $\begin{array}{l}\text { Mucilloid } \\
\text { alone }\end{array}$ & 1 & $0 \mathrm{a}^{\mathrm{z}}$ & $0 \mathrm{a}$ & $0 \mathrm{a}$ & $11 \mathrm{a}$ & $19 a b$ & $67 a b$ & $0 \mathrm{a}$ & $0 \mathrm{a}$ & $11 \mathrm{a}-\mathrm{c}$ & $0 \mathrm{a}$ & $0 \mathrm{a}$ & $30 \mathrm{a}$ & $0 \mathrm{a}$ & $0 \mathrm{a}$ & $0 \mathrm{a}$ \\
\hline Mycelium & 1 & $24 \mathrm{ab}$ & $76 \mathrm{~b}$ & $100 \mathrm{~b}$ & $16 \mathrm{a}$ & $57 \mathrm{~b}$ & $64 \mathrm{a}$ & $6 \mathrm{a}$ & $44 \mathrm{ab}$ & $71 \mathrm{~b}$ & $8 \mathrm{ab}$ & $69 \mathrm{~b}$ & $100 \mathrm{c}$ & $0 \mathrm{a}$ & $2 \mathrm{a}$ & $8 \mathrm{a}$ \\
\hline $\begin{array}{l}1.0 \times 10^{6} \\
\text { conidia/ml }\end{array}$ & 1 & $22 \mathrm{ab}$ & $80 \mathrm{~b}$ & $93 \mathrm{~b}$ & $3 \mathrm{a}$ & $10 a b$ & $57 \mathrm{a}$ & $4 \mathrm{a}$ & $49 \mathrm{~b}$ & $78 \mathrm{~b}$ & $11 a b$ & $67 \mathrm{~b}$ & $84 \mathrm{bc}$ & $3 \mathrm{a}$ & $6 \mathrm{a}$ & $27 \mathrm{~b}$ \\
\hline $\begin{array}{l}6.0 \times 10^{7} \\
\text { conidia/ml }\end{array}$ & 1 & $73 \mathrm{~b}$ & $88 \mathrm{~b}$ & $93 \mathrm{~b}$ & $7 \mathrm{a}$ & $34 \mathrm{~b}$ & $67 a b$ & $0 \mathrm{a}$ & $56 \mathrm{~b}$ & $56 \mathrm{ab}$ & $34 \mathrm{~b}$ & $92 \mathrm{bc}$ & $100 \mathrm{c}$ & $1 \mathrm{a}$ & $7 \mathrm{a}$ & $29 \mathrm{~b}$ \\
\hline $\begin{array}{l}\text { Mucilloid } \\
\text { alone }\end{array}$ & 2 & $0 \mathrm{a}$ & $0 \mathrm{a}$ & $40 \mathrm{ab}$ & $0 \mathrm{a}$ & $0 \mathrm{a}$ & $87 \mathrm{~b}$ & $0 \mathrm{a}$ & $0 \mathrm{a}$ & $0 \mathrm{c}$ & $0 \mathrm{a}$ & $0 \mathrm{a}$ & $68 \mathrm{~b}$ & $0 \mathrm{a}$ & $0 \mathrm{a}$ & $0 \mathrm{a}$ \\
\hline Mycelium & 2 & $40 \mathrm{ab}$ & $70 \mathrm{~b}$ & $79 \mathrm{~b}$ & $4 \mathrm{a}$ & $29 \mathrm{ab}$ & $38 \mathrm{a}$ & $0 \mathrm{a}$ & $24 a b$ & $64 \mathrm{ab}$ & $3 \mathrm{a}$ & $79 \mathrm{~b}$ & $100 \mathrm{c}$ & $0 \mathrm{a}$ & $8 \mathrm{a}$ & $23 \mathrm{~b}$ \\
\hline $\begin{array}{l}1.0 \times 10^{6} \\
\text { conidia/ml }\end{array}$ & 2 & $38 \mathrm{ab}$ & $66 \mathrm{~b}$ & $97 \mathrm{~b}$ & $11 \mathrm{a}$ & $77 \mathrm{~b}$ & $80 \mathrm{ab}$ & $4 \mathrm{a}$ & $70 \mathrm{~b}$ & $93 \mathrm{~b}$ & $17 \mathrm{ab}$ & $91 \mathrm{bc}$ & $100 \mathrm{c}$ & $2 \mathrm{a}$ & $11 \mathrm{a}$ & $36 \mathrm{~b}$ \\
\hline $\begin{array}{l}6.0 \times 10^{7} \\
\text { conidia/ml }\end{array}$ & 2 & $48 \mathrm{ab}$ & $81 \mathrm{~b}$ & $100 \mathrm{~b}$ & $41 \mathrm{a}$ & $54 \mathrm{~b}$ & $94 \mathrm{~b}$ & $4 \mathrm{a}$ & $56 \mathrm{~b}$ & $81 \mathrm{~b}$ & $37 \mathrm{~b}$ & $100 \mathrm{bc}$ & $100 \mathrm{c}$ & $2 \mathrm{a}$ & $5 \mathrm{a}$ & $18 \mathrm{ab}$ \\
\hline
\end{tabular}

${ }^{\mathrm{x}}$ Data represent the average percent mortality in five replications of each treatment for each species.

y Triazine-resistant biotype.

${ }^{\mathrm{z}}$ Percentages within columns with the same letter are not significantly different $(P=0.05)$ according to mean separation by the least-squares means tests based on the arcsine square-root transformed proportions using repeated measures analysis. No species-wise comparisons were made.

Table 2. Pigweed (Amaranthus spp.) mortality at 2, 4, and 6 weeks after inoculation with Phomopsis amaranthicola in the 1994 field trial

\begin{tabular}{|c|c|c|c|c|c|c|c|c|c|c|c|c|c|c|c|c|}
\hline \multirow[b]{3}{*}{ Treatment } & \multirow[b]{3}{*}{ Applic. } & \multicolumn{15}{|c|}{ Percent mortality $^{x}$} \\
\hline & & \multicolumn{3}{|c|}{ A. lividus } & \multicolumn{3}{|c|}{ A. viridus } & \multicolumn{3}{|c|}{ A. spinosus } & \multicolumn{3}{|c|}{ A. hybridus } & \multicolumn{3}{|c|}{ A. hybridus ${ }^{\mathrm{y}}$} \\
\hline & & $2 \mathrm{wk}$ & 4 wk & $6 \mathrm{wk}$ & $2 \mathrm{wk}$ & 4 wk & $6 \mathrm{wk}$ & 2 wk & 4 wk & $6 \mathrm{wk}$ & 2 wk & $4 \mathrm{wk}$ & $6 \mathrm{wk}$ & 2 wk & $4 \mathrm{wk}$ & $6 \mathrm{wk}$ \\
\hline $\begin{array}{l}\text { Mucilloid } \\
\text { alone }\end{array}$ & 1 & $0 \mathrm{a}^{\mathrm{z}}$ & $12 \mathrm{a}$ & $72 \mathrm{a}$ & $0 \mathrm{a}$ & $4 \mathrm{a}$ & $73 \mathrm{a}$ & $0 \mathrm{a}$ & 4 a & $6 \mathrm{a}$ & $0 \mathrm{a}$ & $16 \mathrm{a}$ & 20 a & $0 \mathrm{a}$ & $0 \mathrm{a}$ & 39 a \\
\hline Mycelium & 1 & $1 \mathrm{a}$ & $22 a b$ & $79 \mathrm{a}$ & $0 \mathrm{a}$ & $18 a b$ & $87 \mathrm{a}$ & $0 \mathrm{a}$ & $2 \mathrm{a}$ & $46 \mathrm{~b}$ & $0 \mathrm{a}$ & $0 \mathrm{a}$ & $0 \mathrm{a}$ & $0 \mathrm{a}$ & $0 \mathrm{a}$ & $2 a b$ \\
\hline $\begin{array}{l}1.0 \times 10^{6} \\
\text { conidia/ml }\end{array}$ & 1 & $0 \mathrm{a}$ & $80 \mathrm{bc}$ & $100 \mathrm{a}$ & $0 \mathrm{a}$ & $58 \mathrm{bc}$ & $96 \mathrm{a}$ & $0 \mathrm{a}$ & 16 a & $70 \mathrm{~b}$ & $0 \mathrm{a}$ & $0 \mathrm{a}$ & $0 \mathrm{a}$ & $0 \mathrm{a}$ & $0 \mathrm{a}$ & $5 \mathrm{ab}$ \\
\hline $\begin{array}{l}6.0 \times 10^{7} \\
\text { conidia/ml }\end{array}$ & 1 & $12 \mathrm{a}$ & $87 \mathrm{c}$ & $100 \mathrm{a}$ & $9 \mathrm{a}$ & $44 \mathrm{~b}$ & $92 \mathrm{a}$ & $1 \mathrm{a}$ & $31 \mathrm{ab}$ & $61 \mathrm{~b}$ & $0 \mathrm{a}$ & $1 \mathrm{a}$ & $0 \mathrm{a}$ & $0 \mathrm{a}$ & $0 \mathrm{a}$ & $27 \mathrm{a}$ \\
\hline $\begin{array}{l}\text { Mucilloid } \\
\text { alone }\end{array}$ & 2 & $3 \mathrm{a}$ & $12 \mathrm{a}$ & $80 \mathrm{a}$ & $0 \mathrm{a}$ & $1 \mathrm{a}$ & $68 \mathrm{a}$ & $0 \mathrm{a}$ & $0 \mathrm{a}$ & $8 \mathrm{a}$ & $0 \mathrm{a}$ & $0 \mathrm{a}$ & $6 \mathrm{a}$ & $0 \mathrm{a}$ & $0 \mathrm{a}$ & $0 \mathrm{~b}$ \\
\hline Mycelium & 2 & $3 \mathrm{a}$ & $32 \mathrm{ab}$ & $80 \mathrm{a}$ & $0 \mathrm{a}$ & $5 \mathrm{ab}$ & $70 \mathrm{a}$ & $0 \mathrm{a}$ & $3 \mathrm{a}$ & $35 \mathrm{a}$ & $0 \mathrm{a}$ & $0 \mathrm{a}$ & $0 \mathrm{a}$ & $0 \mathrm{a}$ & $1 \mathrm{a}$ & $3 a b$ \\
\hline $\begin{array}{l}1.0 \times 10^{6} \\
\text { conidia/ml }\end{array}$ & 2 & $0 \mathrm{a}$ & $81 \mathrm{bc}$ & $82 \mathrm{a}$ & $0 \mathrm{a}$ & $57 \mathrm{~b}$ & $96 \mathrm{a}$ & $1 \mathrm{a}$ & $12 \mathrm{a}$ & 36 a & $0 \mathrm{a}$ & $0 \mathrm{a}$ & $0 \mathrm{a}$ & $0 \mathrm{a}$ & $2 \mathrm{a}$ & $5 a b$ \\
\hline $\begin{array}{l}6.0 \times 10^{7} \\
\text { conidia/ml }\end{array}$ & 2 & $9 \mathrm{a}$ & $95 \mathrm{c}$ & 97 a & $1 \mathrm{a}$ & $41 \mathrm{~b}$ & $86 \mathrm{a}$ & $1 \mathrm{a}$ & $39 \mathrm{~b}$ & $62 \mathrm{~b}$ & $0 \mathrm{a}$ & $0 \mathrm{a}$ & $15 \mathrm{a}$ & $0 \mathrm{a}$ & $1 \mathrm{a}$ & $6 a b$ \\
\hline
\end{tabular}

${ }^{\mathrm{x}}$ Data represent the average percent mortality in five replications of each treatment for each species.

y Triazine-resistant biotype.

${ }^{\mathrm{z}}$ Percentages within columns with the same letter are not significantly different $(P=0.05)$ according to mean separation by the least-squares means tests based on the arcsine square-root transformed proportions using repeated measures analysis. No species-wise comparisons were made. 
the high concentration of conidia, but this was not different from mortality in other treatments, except in a single application of a low concentration of conidia.

Six weeks after inoculation, all plots of A. lividus, including controls, had greater than $95 \%$ mortality (Table 3). No significant differences existed between the treatments in A. viridus plots, with plant mortality ranging between 25 and $64 \%$. Control of $A$. spinosus approached $100 \%$ in fungus-treated plots, but no significant differences were detected between treatments and controls. Mortality in the triazine-sensitive $A$. hybridus plots reached $74 \%$ in treated plots and $50 \%$ in controls, but there were few differences among treatments by 6 weeks after inoculation. The triazine-resistant $A$. hybridus accession reached $61 \%$ plant mortality after treatment with a double application of the high concentration of conidia. Mortality in control plots reached $37 \%$, and there were no differences detected among any treatments.

\section{DISCUSSION}

P. amaranthicola was capable of killing some of the Amaranthus spp. plants in the field. The application of the humectant also had a significant impact on plant mortality by promoting disease incidence. This factor was also conducive to the spread of the pathogen to non-fungus-treated controls. Movement of the pathogen to control plots could be visually detected within 2 weeks of application. While plant mortality occurred more quickly in fungus-treated plots, by 6 weeks after inoculation, few significant differences existed between control and initially inoculated plots. Control of A. lividus was excellent in all 3 years of testing, with $100 \%$ plant mortality resulting from at least one treatment each year. Conidia were generally more effective in causing plant mortality, but this was variable from species to species and year to year. Overall plant mortality was greatest in the 1993 and 1995 studies. This may have been influenced by the higher maximum relative humidity levels during the period of inoculation and disease onset (about 90\% in 1993 and 1995 compared with approximately $75 \%$ in 1994). The maximum relative humidity in 1995 was highest of the 3 years studied and had the greatest amount of rainfall, while rainfall in 1993 was the least of the 3 years. The minimum and maximum temperatures during the periods of the studies did not appear to be highly variable from year to year, although this factor has been reported as being less significant in terms of disease development by species of Phomopsis $(5,12)$.

All species of Amaranthus tested were controlled in at least 1 year of the study, except for the triazine-resistant accession of A. hybridus. This is explained on the basis of the age of these plants at the time of fungal treatments. The triazine-resistant and the triazine-susceptible accessions had faster growth rates compared with the other species, and these plants were approaching the six-leaf stage by the time the fungus was applied. It has been previously established that mature plants are more resistant to $P$. amaranthicola than younger plants (10).

An experimental design that included buffer rows of immune plants, as used in field trials of the efficacy of Collego for the control of northern jointvetch (Aeschynomene virginica), could have provided a means to confine secondary spread of $P$. amaranthicola and allowed more valid comparisons between inoculated plots and controls. This comparison was further complicated in the 1995 trial with the additional effect of the insect larval population. Not only were plants affected by the larvae, but there was the possibility that inoculum was spread by the larvae as well (13).
In evaluating the effect of environmental factors on the spread and severity of disease caused by Phomopsis longicolla in soybean, it was reported (12) that rain, duration of surface wetness, and relative humidity were the most important factors in disease development. Rain events were the primary means of dispersal of the pathogen. TeKrony et al. (14) also found that disease intensity caused by Phomopsis spp. in soybean was dependent more on moisture than on temperature. Conversely, Uddin (15) reported that the temperature had an effect on the growth of Phomopsis spp. on peach in the field. The former case appears to be more representative of the results with $P$. amaranthicola for the control of Amaranthus spp.

Two additional aspects of the field results are important to consider. There were few statistically significant differences between treated and control plots by 6 weeks after inoculation, and the effects seen in the control plots resulted from the spread of $P$. amaranthicola, indicating the possibility of secondary inoculum production in the field. It is unclear if this secondary inoculum would have caused significant damage to control plots if they had not been previously treated with the mucilloid. However, the ability of the pathogen to spread is a positive feature of this biocontrol agent. The ability to spread and establish secondary infection foci in the field could aid in controlling disease-escapes as well as newly emerged pigweed plants.

Thus, consistently high levels of mortality were achieved with three of the four pigweed species and two accessions tested. The weed control was achieved within an acceptable period of time. These findings, coupled with the high degree of host specificity of this fungus $(10,11)$, indicate that $P$. amaranthicola holds promise as a bioherbicide to control weedy species of pigweeds and amaranths.

Table 3. Pigweed (Amaranthus spp.) mortality at 2, 4, and 6 weeks after inoculation with Phomopsis amaranthicola in the 1995 field trial

\begin{tabular}{|c|c|c|c|c|c|c|c|c|c|c|c|c|c|c|c|c|}
\hline \multirow[b]{3}{*}{ Treatment } & \multirow[b]{3}{*}{ Applic. } & \multicolumn{15}{|c|}{ Percent mortality $^{\mathrm{x}}$} \\
\hline & & \multicolumn{3}{|c|}{ A. lividus } & \multicolumn{3}{|c|}{ A. viridus } & \multicolumn{3}{|c|}{ A. spinosus } & \multicolumn{3}{|c|}{ A. hybridus } & \multicolumn{3}{|c|}{ A. hybridus ${ }^{y}$} \\
\hline & & $2 \mathrm{wk}$ & 4 wk & $6 \mathrm{wk}$ & $2 \mathrm{wk}$ & $4 \mathrm{wk}$ & $6 \mathrm{wk}$ & $2 \mathrm{wk}$ & $4 \mathrm{wk}$ & $6 \mathrm{wk}$ & $2 \mathrm{wk}$ & $4 \mathrm{wk}$ & 6 wk & $2 \mathrm{wk}$ & $4 \mathrm{wk}$ & $6 \mathrm{wk}$ \\
\hline $\begin{array}{l}\text { Mucilloid } \\
\text { alone }\end{array}$ & 1 & $0 \mathrm{a}^{\mathrm{z}}$ & $22 \mathrm{a}$ & $100 \mathrm{a}$ & $0 \mathrm{a}$ & $15 \mathrm{a}$ & $53 \mathrm{a}$ & $16 \mathrm{ab}$ & $36 \mathrm{ab}$ & $81 \mathrm{a}$ & $0 \mathrm{a}$ & $10 \mathrm{a}$ & $32 \mathrm{a}$ & $0 \mathrm{a}$ & $6 \mathrm{a}$ & $37 \mathrm{a}$ \\
\hline Mycelium & 1 & $0 \mathrm{a}$ & $23 \mathrm{a}$ & $100 \mathrm{a}$ & $0 \mathrm{a}$ & $9 \mathrm{a}$ & $35 \mathrm{a}$ & $17 \mathrm{ab}$ & $26 \mathrm{ab}$ & $46 \mathrm{a}$ & $5 \mathrm{a}$ & $13 \mathrm{a}$ & $56 \mathrm{ab}$ & $0 \mathrm{a}$ & $11 \mathrm{a}$ & $48 \mathrm{a}$ \\
\hline $\begin{array}{l}1.0 \times 10^{6} \\
\text { conidia/ml }\end{array}$ & 1 & $3 \mathrm{a}$ & $52 \mathrm{ab}$ & 99 a & $0 \mathrm{a}$ & $10 \mathrm{a}$ & $25 \mathrm{a}$ & $4 \mathrm{a}$ & $18 \mathrm{a}$ & $76 \mathrm{a}$ & $3 \mathrm{a}$ & $5 \mathrm{a}$ & $74 \mathrm{~b}$ & $1 \mathrm{a}$ & $20 \mathrm{a}$ & $44 \mathrm{a}$ \\
\hline $\begin{array}{l}6.0 \times 10^{7} \\
\text { conidia/ml }\end{array}$ & 1 & $26 \mathrm{a}$ & $62 \mathrm{ab}$ & $100 \mathrm{a}$ & $0 \mathrm{a}$ & $12 \mathrm{a}$ & $64 \mathrm{a}$ & $29 \mathrm{~b}$ & $53 \mathrm{ab}$ & $100 \mathrm{a}$ & $0 \mathrm{a}$ & $13 \mathrm{a}$ & $36 \mathrm{a}$ & $0 \mathrm{a}$ & $20 \mathrm{a}$ & $44 \mathrm{a}$ \\
\hline $\begin{array}{l}\text { Mucilloid } \\
\text { alone }\end{array}$ & 2 & $0 \mathrm{a}$ & $16 \mathrm{a}$ & 97 a & $0 \mathrm{a}$ & $8 \mathrm{a}$ & $40 \mathrm{a}$ & $19 \mathrm{ab}$ & $59 \mathrm{ab}$ & $73 \mathrm{a}$ & $0 \mathrm{a}$ & $26 \mathrm{a}$ & $50 \mathrm{ab}$ & $0 \mathrm{a}$ & $8 \mathrm{a}$ & $33 \mathrm{a}$ \\
\hline Mycelium & 2 & $0 \mathrm{a}$ & $15 \mathrm{a}$ & $100 \mathrm{a}$ & $0 \mathrm{a}$ & $15 \mathrm{a}$ & $45 \mathrm{a}$ & $4 \mathrm{a}$ & $26 \mathrm{ab}$ & $62 \mathrm{a}$ & $1 \mathrm{a}$ & $6 \mathrm{a}$ & $69 \mathrm{ab}$ & $0 \mathrm{a}$ & $16 \mathrm{a}$ & $28 \mathrm{a}$ \\
\hline $\begin{array}{l}1.0 \times 10^{6} \\
\text { conidia/ml }\end{array}$ & 2 & 8 a & $40 \mathrm{ab}$ & $100 \mathrm{a}$ & $5 \mathrm{a}$ & $18 \mathrm{a}$ & $38 \mathrm{a}$ & $3 a$ & $49 \mathrm{ab}$ & $97 \mathrm{a}$ & $0 \mathrm{a}$ & $8 \mathrm{a}$ & $70 a b$ & $1 \mathrm{a}$ & $6 \mathrm{a}$ & $44 \mathrm{a}$ \\
\hline $\begin{array}{l}6.0 \times 10^{7} \\
\text { conidia/ml }\end{array}$ & 2 & $9 \mathrm{a}$ & $73 \mathrm{~b}$ & $100 \mathrm{a}$ & $6 \mathrm{a}$ & $14 \mathrm{a}$ & $63 \mathrm{a}$ & $38 \mathrm{~b}$ & $78 \mathrm{~b}$ & $78 \mathrm{a}$ & $0 \mathrm{a}$ & $3 \mathrm{a}$ & $33 \mathrm{a}$ & $1 \mathrm{a}$ & $7 \mathrm{a}$ & $61 \mathrm{a}$ \\
\hline
\end{tabular}

$\bar{x}$ Data represent the average percent mortality in five replications of each treatment for each species.

y Triazine-resistant biotype.

${ }^{\mathrm{z}}$ Percentages within columns with the same letter are not significantly different $(P=0.05)$ according to mean separation by the least-squares means tests based on the arcsine square-root transformed proportions using repeated measures analysis. No species-wise comparisons were made. 


\section{ACKNOWLEDGMENTS}

We thank David Brenner of the North Central Regional Plant Introduction Station in Ames, IA, for providing seeds of the Amaranthus spp. tested and Jay Harrison, Statistics Department, University of Florida, for his assistance with statistical analyses.

\section{LITERATURE CITED}

1. Auld, B. A., Say, M. M., Ridings, H. I., and Andrews, J. 1990. Field application of Colletotrichum orbiculare to control Xanthium spinosum. Agric. Ecosyst. Env. 32:315-323.

2. Baudoin, A. B. A. M., Abad, R. G., Kok, L. T., and Bruckart, W. L. 1993. Field evaluation of Puccinia carduorum for biological control of musk thistle. Biol. Control 3:53-60.

3. Boyette, C. D., Quimby, P. C., Bryson, C. T., Egley, G. H., and Fulgham, F. E. 1993. Biological control of hemp sesbania (Sesbania exaltata) under field conditions with Colletotrichum truncatum formulated in an invert emulsion. Weed Sci. 41:497-500.

4. Daniel, J. T., Templeton, G. E., Smith, R. J., and Fox, W. T. 1973. Biological control of northern jointvetch in rice with an endemic fungal disease. Weed Sci. 21:303-307.

5. Eshenaur, B. C., and Milholland, R. D. 1989. Factors influencing the growth of Phomopsis obscurans and disease development on strawberry leaf and runner tissue. Plant Dis. 73:814-819.

6. Kahn, H. A., and Sempos, C. T. 1989. Statistical Methods in Epidemiology. Monographs on Epidemiology and Biostatistics, Vol. 12. Oxford University Press, New York.

7. Klein, T. A., Auld, B. A., and Fang, W. 1995. Evaluation of oil suspension emulsions of Colletotrichum orbiculare as a mycoherbicide in-field trials. Crop Prot. 14:193-197.

8. Mintz, A. S., Heiny, D. K., and Weidemann, G. J. 1992. Factors influencing the biocontrol of tumble pigweed (Amaranthus albus) with Aposphaeria amaranthi. Plant Dis. 76:267-269.

9. Ridings, W. H., Mitchell, D. J., Schoulties, C. L., and El-Gholl, N. E. 1976. Biological control of milkweed vine in Florida citrus groves with a pathotype of Phytophthora citrophthora. Pages 224-240 in: Proc. IV Int. Symp. Biol. Control Weeds. T. E. Freeman, ed. University of Florida, Gainesville.
10. Rosskopf, E. N. 1997. Evaluation of Phomopsis amaranthicola sp. nov. as a biological control agent for Amaranthus spp. Ph.D. diss. University of Florida, Gainesville.

11. Rosskopf, E. N., Charudattan, R., Shabana, Y. M., Benny, G. L. 2000. Phomopsis amaranthicola, a new species from Amaranthus sp. Mycologia 92:114-122.

12. Rupe, J. C., and Ferris, R. S. 1987. A model for predicting the effects of microclimate on infection of soybean by Phomopsis longicolla. Phytopathology 77:1162-1166.

13. Shivas, R. G., and Scott, J. K. 1993. Effect of the stem blight pathogen, Phomopsis emicis, and the weevil, Perapion antiquum, on the weed Emex australis. Ann. Appl. Biol. 122:617-622.

14. TeKrony, D. M., Egli, D. B., Stuckey, R. E., and Balles, J. 1983. Relationship between weather and soybean seed infection by Phomopsis sp. Phytopathology 73:914-918.

15. Uddin, W. 1996. Epidemiology and Management of Phomopsis Shoot Blight of Peach, Prunus persica (L.) Batsch. Ph.D. diss. University of Georgia, Athens. 